\title{
RANCANG BANGUN APLIKASI SISTEM PENDUKUNG KEPUTUSAN SELEKSI PEMILIHAN DESTINASI PARIWISATA SUMATERA BARAT MENGGUNAKAN METODE ELECTRE
}

\author{
Dony Novaliendry ${ }^{1}$, Yuli Pusparani ${ }^{2}$ \\ ${ }^{1,2}$ Prodi Pendidikan Teknik Informatika, Universitas Negeri Padang \\ E-mail : ${ }^{1}$ dony.novaliendry@ft.unp.ac.id, ${ }^{2}$ pusparani.yuli@gmail.com
}

\begin{abstract}
Tourism is one of the activities carried out by humans that has a purpose as entertainment. Human who travel are referred to as tourist. West Sumatra Province is one of the regions with the best tourism is sea tourism and land tourism. Marine tourism consists of beach tourism, island tourism and lake tourism, while mainland tourism consists of tourist panorama, mountain tours, hill tours and others. However, only a portion of West Sumatra's tourist attractions are known to tourists, because of this information is obtained so that there are still many tourist attractions in West Sumatra unknown to tourists from outside the West Sumatra region. To overcome this problem, a system is needed that can be used to support the electoral decision-making process in West Sumatra. This system is built on the Web, using the PHP programming language and Laravel Framework and MYSQL as a Database. The method used in this system is the Elimination of Et Choix Traduisant la Realite (ELECTRE). The use of Elimination Et Choix Traduisant la REalite (ELECTRE) can help provide information in West Sumatra, which is in accordance with the wishes of tourists according to the specified criteria. With the help of this system, the information obtained will make it easier for tourists to find tourist attractions.
\end{abstract}

Keywords: Decision Support System, Elimination of Et Choix Traduisant la REalite (ELECTRE), Laravel, Tourism.

\section{INTISARI}

Pariwisata merupakan salah satu kegiatan yang dilakukan manusia yang mempunyai tujuan unutk sebagai hiburan. Manusia yang melakukan perjalanan wisata disebut sebagai wisatawan. Provinsi Sumatera Barat merupakan salah satu wilayah pariwisata dengan wisata terbaik seperti wisata laut dan wisata darat. Wisata laut yang terdiri dari wisata pantai, wisata pulau dan wisata danau, sedangkan wisata darat terdiri dari wisata panorama, wisata pegunungan, wisata bukit dan lain-lain. Namun, karena kurangnya informasi, hanya sebahagian objek wisata Sumatera Barat yang dikenal oleh wisatawan. Untuk mengatasi permasalahan tersebut, maka dibutuhkan suatu sistem yang dapat digunakan untuk mendukung proses pengambilan keputusan pemilihan destinasi pariwisata di Sumatera Barat. Sistem ini dibangun berbasis Web, menggunakan bahasa pemrograman PHP serta berbasis Framework Laravel dan MySQL sebagai Database. Metode yang digunakan dalam sistem ini adalah Elimination Et Choix Traduisant la Realite (ELECTRE). Penggunaan dari Elimination Et Choix Traduisant la REalite (ELECTRE) dapat membantu memberikan informasi pariwisata di Sumatera Barat, yang sesuai dengan keinginan wisatawan berdasarkan kriteria yang ditetapkan. Dengan bantuan sistem ini, maka informasi yang didapat akan lebih memudahkan wisatawan dalam mencari tempat wisata.

Kata Kunci : Sistem Pendukung Keputusan, Elimination Et Choix Traduisant la REalite (ELECTRE), Laravel, Pariwisata.

\section{PENDAHULUAN}

Industri pariwisata saat ini merupakan salah satu sektor pendapatan yang sangat besar dampaknya dikenal daerah. Daerah-daerah di Indonesia memiliki kekayaan alam dan budaya yang dikembangkan menjadi sebuah wisata yang 
bisa dinikmati. Sehingga tidak heran banyak wisatawan baik wisatawan dalam negeri yang berlibur ke daerah yang ada di Indonesia.[1]

Povinsi Sumatera Barat merupakan salah satu wilayah yang memiliki tempat wisata terbaik yaitu dikenal dengan wisata laut dan wisata darat. salah satu wisata laut yaitu kawasan laut siberut dan sekitarnya yang memiliki sektor unggul perikanan, wisata pantai, wisata pulau dan wisata danau. Sedangkan wisata darat adalah wisata keindahan kota, wisata panorama, wisata pegunungan dan lain-lain.

Provinsi Sumatera Barat memiliki 19 Kabupaten/Kota, setiap Kabupaten/Kota memiliki Dinas Pariwisata dan Budaya. Website yang dibangun oleh Dinas Pariwisata Provinsi Sumatera Barat memberikan informasi seputar pariwisata yang ada didaerah tersebut. Namun tidak semua wisatawan yang menerima hasil informasi secara puas, dikarenakan tidak adanya Website yang memberikan informasi lengkap seputar data pariwisata yang terletak di seluruh daerah Sumatera Barat. [2]

Dengan demikian dari permasalahan tersebut, maka dibutuhkan sistem yang memiliki fungsi untuk penginputan data dan perankingan nilai supaya wisatawan dapat menentukan pilihan tempat wisata yang akan dikunjungin sesuai keinginan dan kondisi wisatawan. Hal inilah mendorong penulis untuk mengembangkan Sistem Pendukung Keputusan Seleksi Pemilihan Destinasi Pariwisata Berdasarkan keinginan dan kondisi wisatawan, dimana diharapkan dengan adanya sistem ini akan dapat mengatasi permasalahan.

Sistem yang akan dibangun adalah sistem pendukung keputusan yang Sistem Pendukung Keputusan (SPK) adalah informasi berbasis computer yang menghasilkan berbagai alternatif keputusan untuk membantu manajemen dalam menangani berbagai permasalahan yang terstruktur ataupun tidak terstruktur dengan menggunakan data. Tujuan SPK untuk mendukung pengambilan keputusan memilih alternatif hasil pengolahan data informasi dengan metode serta menyelesaikan masalah yang ditemukan.

\section{Sistem Pendukung Keputusan}

Sistem Pendukung Keputusan (SPK) adalah informasi berbasis komputer yang menghasilkan berbagai alternatif keputusan untuk membantu manajemen dalam menangani berbagai permasalahan yang terstruktur ataupun tidak terstruktur dengan menggunakan data. Alter [3] mendefinisikan SPK sebagai sistem informasi interaktif yang menyediakan informasi, dan pemodelan. Tujuan SPK untuk mendukung pengambilan keputusan memilih alternatif hasil pengolahan data informasi dengan metode serta menyelesaikan masalah yang ditemukan.[4]

Model yang menggambarkan proses pendukung keputusan terdiri dari empat fase, yaitu[5]:

1. Penelusuran (Intelligence)

2. Perancangan (Design)

3. Pemilihan (Choice)

4. Implementasi (Implementation)

\section{Multiple Crteria Decision Making (MCDM)}

Multiple Crteria Decision Making (MCDM) merupakan teknik pengambilan keputusan dari beberapa pilihan alternatif yang ada.[6] Pengamblan keputusan dilakukan melalui pemilihan atau melakukan formulasi atributatribut,objektif-objektif, maupun tujun-tujuan yang berbeda. Maka atribut,objektif maupun tujuan dianggap sebagai kriteria. Kriteria yang dibangun dari kebutuhan dasar manusia serta nilai-nilai yang diinginkan.

\section{Elimination Et Choix Traduisant la REalite (ELECTRE)}

Elimination Et Choix Traduisant la REalite (ELECTRE) merupakan salah satu metode yang digunakan untuk sistem pendukung keputusan yang berdasarkan konsep outranking,[7] dimana di sistem yang akan dirancang, setiap alternatif yang akan dipilih memiliki kriteria yang mempunyai bobot nilai yang akan dihitung menggunakan rumus metode ELECTRE. Setelah nilai sudah dihitung maka akan ditemukanlah alternatif yang sesuai dengan keinginan wisatawan di pariwisata Sumatera Barat.

Langkah-langkah yang dilakukan dalam penyelesaian masalah menggunakan metode electre adalah sebagai berikut:

1. Normalisasi matrik keputusan, yaitu setiap atribut diubah menjadi nilai. Setiap normalisasi dari nilai $r_{i j}$ dapat dilakukan dengan rumus sebagai berikut:

$$
r_{i j}=\frac{x_{i j}}{\sqrt{\sum_{i=1}^{m} x^{2}}} \text {, untuk } i=1,2,3, \ldots, m \text { dan } j=1,2,3, \ldots, n \text {. }
$$


Sehingga didapat matriks $\mathrm{R}$ hasil normalisasi,

$$
R=\left[\begin{array}{llll}
r_{11} & r_{12} & \ldots & r_{1 \mathrm{n}} \\
r_{21} & r_{22} & \ldots & r_{2 \mathrm{n}} \\
\ldots & & & \\
r_{m 1} & r_{m 2} & \ldots & r_{m n}
\end{array}\right]
$$

$\mathrm{R}$ merupakan matriks yang telah dinormalisasi, dimana $\mathrm{m}$ adalah alternatif, $\mathrm{n}$ adalah kriteria dan $r_{i j}$ adalah normalisasi.

2. Pembobotan pada matrik yang telah di normalisasi, yaitu setelah di normalisasi selanjutnya kolom dari matrik $\mathrm{R}$ di kalikan dengan bobot $w_{j}$ yang di tentukan oleh pembuat keputusan. Sehingga V=RW yang ditulis dalam Rumus sebagai berikut:

$$
\begin{aligned}
V & =\left[\begin{array}{llll}
v_{11} & v_{12} & \ldots & v_{1 \mathrm{n}} \\
v_{21} & v_{22} & \ldots & v_{2 \mathrm{n}} \\
\ldots & & & \\
v_{m 1} & v_{m 2} & \ldots & v_{m n}
\end{array}\right]= \\
R W & =\left[\begin{array}{llll}
w_{1} r_{11} & w_{2} r_{12} & \ldots & w_{n} r_{1 \mathrm{n}} \\
w_{1} r_{21} & w_{2} r_{22} & \ldots & w_{n} r_{2 \mathrm{n}} \\
\ldots & & & \\
w_{1} r_{m 1} & w_{2} r_{m 2} & \ldots & w_{n} r_{m n}
\end{array}\right] \quad \ldots .
\end{aligned}
$$

Dimana W adalah

$$
W=\left[\begin{array}{ccccc}
w_{1} & 0 & 0 & \ldots & 0 \\
0 & w_{2} & 0 & \ldots & \\
\ldots & & & & \\
0 & 0 & 0 & \ldots & w_{n}
\end{array}\right] \text {, dan } \sum_{i=1}^{n} w=1
$$

3. Menentukan concordance dan discordance set, yaitu sebuah kriteria dalam suatu alternatif termasuk concordance adalah :

$$
C_{k l}=\left\{j, y_{k j} \geq y_{l j}\right\}, \text { untuk } j=1,2,3, \ldots, n
$$

Sedangkan yang termasuk discordance adalah:

$$
D_{k l}=\left\{j, y_{k j}<y_{l j}\right\}, \text { untuk } j=1,2,3, \ldots, n
$$

4. Hitung matriks concordance dan discordance.

a. Concordance

Untuk menjumlahkan bobot-bobot secara matematis adalah pada Rumus berikut:

$$
c_{k l}=\sum_{j C_{w}} w_{j}
$$

Sehingga matrik concordance yang dihasilkan adalah:

$$
C=\left[\begin{array}{lllll}
- & c_{12} & c_{13} & \ldots & c_{1 \mathrm{n}} \\
c_{21} & - & c_{23} & \ldots & c_{2 \mathrm{n}} \\
\ldots & & & & \\
c_{m 1} & c_{m 2} & c_{m 3} & \ldots & -
\end{array}\right]
$$

b. Discordance

Untuk membagi maksimum selisih nilai kriteria secara matematis adalah pada Rumus berikut:

$$
d_{k l}=\frac{\left\{\max \left(v_{m n}-v_{m n-1 \mathrm{n}}\right)\right\} ; m, n \in D_{k l}}{\left\{\max \left(v_{m n}-v_{m n-\mathrm{ln}}\right)\right\} ; m, n=1,2,3, \ldots}
$$

Sehingga matrik discordance yang dihasilkan adalah:

$$
D=\left[\begin{array}{lllll}
- & d_{12} & d_{13} & \ldots & d_{1 \mathrm{~m}} \\
d_{21} & - & d_{23} & \ldots & c_{2 \mathrm{~m}} \\
\ldots & & & & \\
d_{m 1} & d_{m 2} & d_{m 3} & \ldots & -
\end{array}\right]
$$

5. Menetukan matrik dominan concordance dan discordance.

a. Concordance

Matrik dominan concordance dapat dibangun dengan bantuan nilai threshold.

$$
C_{k l} \geq \underline{\underline{c}}
$$

Dengan nilai threshold ( $\underline{\mathrm{c}}$ ), adalah : 


$$
\underline{c}=\frac{\sum_{k=1}^{n} \sum_{l=1}^{n} c_{k l}}{m *(m-1)}
$$

Dan nilai setiap elemen matriks $F$ sebagai matriks dominan concordance yaitu:

$$
\begin{gathered}
f_{k l}=1, j i k a c_{k l} \geq \underline{c} \operatorname{dan} f_{k l}=0, j i k a c_{k l}< \\
\underline{c}
\end{gathered}
$$

b. Discordance

Untuk membangun matriks dominan juga menggunakan bantuan nilai threshold, yaitu:

$$
\underline{d}=\frac{\sum_{k=1}^{n} \sum_{l=1}^{n} d_{k l}}{m *(m-1)}
$$

Dan nilai setiap elemen untuk matriks $G$ sebagai matriks dominan discordance sebagai berikut:

$$
\begin{aligned}
g_{k l}=0, \text { jika } c_{k l} \geq & \underline{d} \text { dan } g_{k l}=1, \text { jika } c_{k l} \\
& <\underline{d}
\end{aligned}
$$

6. Menentukan aggregate dominance matrix, yaitu sebagai matrik E, yag setiap elemennya merupakan perkalian antara elemen $\mathrm{F}$ dengan elemen G, sebagai berikut:

$$
e_{k l}=f_{k l} \times g_{k l}
$$

7. Eliminasi alternatif yang less favoutable, yaitu Matriks E memberikan urutan pilihan dari setiap alternatif.

\section{PENDEKATAN PEMECAHAN \\ MASALAH}

\section{Analisis Sistem}

Provinsi Sumatera Barat mempunyai beberapa objek wisata yang dijadikan tempat wisata di akhir pekan atau ketika liburan. Dapat dilihat dari banyaknya wisatawan yang datang ke lokasi tempat wisata yang dinginkan, setiap wisatawan memiliki beberapa kriteria yang dijadikan sebagai dasar dalam memilih tempat wisata yang diinginkan, yaitu biaya wisata yang harus dikeluarkan, fasilitas yang dimiliki tempat wisata yang ingin dituju dan strategis atau tidaknya tempat wisata tersebut.

Dengan adanya sistem yang akan dibangun ini yaitu sistem pendukung keputusan pemilihan objek wisata berdasarkan kriteria tempat yang diinginkan wisatawan, maka sistem ini akan membantu wisatawan dalam memilih daerah wisata sesuai dengan kriteria yang diinginkan berupa inputan harga wisata, fasilitas wisata, strategis atau tidak tempat wisata.

\section{Perancangan Sistem}

\section{Identifikasi Pelaku Sistem}

Di bawah ini akan dijelaskan pelaku yang terlibat dalam menjalankan sistem pendukung keputusan pemilihan destinasi pariwisata Sumatera Barat pada Tabel 1

Tabel 1.Pelaku Sistem

\begin{tabular}{llr}
\hline Istilah & Deskripsi \\
\hline Admin & $\begin{array}{l}\text { Merupakan pelaku yang akan } \\
\text { mengoperasikan }\end{array}$ \\
& dan \\
& akan disajikan karena admin \\
& mempunyai hak untuk \\
& menambah, mengubah, \\
& menghapus, dan melihat. \\
\hline Petugas & Merupakan pelaku yang akan \\
& mengoperasikan dan \\
& menambahkan konten terbaru \\
\hline Wisatawan/ & Wisatawan/User merupakan \\
User & seseorang yang akan \\
& menggunakan sistem ini yang \\
& merupakan calon pengunjung \\
& Pariwisata Sumatera Barat \\
\hline
\end{tabular}

\section{Use-Case Diagram}

Use-case Diagram berisi mengenai gambaran tentang sistem pariwisata yang akan dibangun. Sistem yang akan dibuat nantinya seperti gambar dibawah ini: 


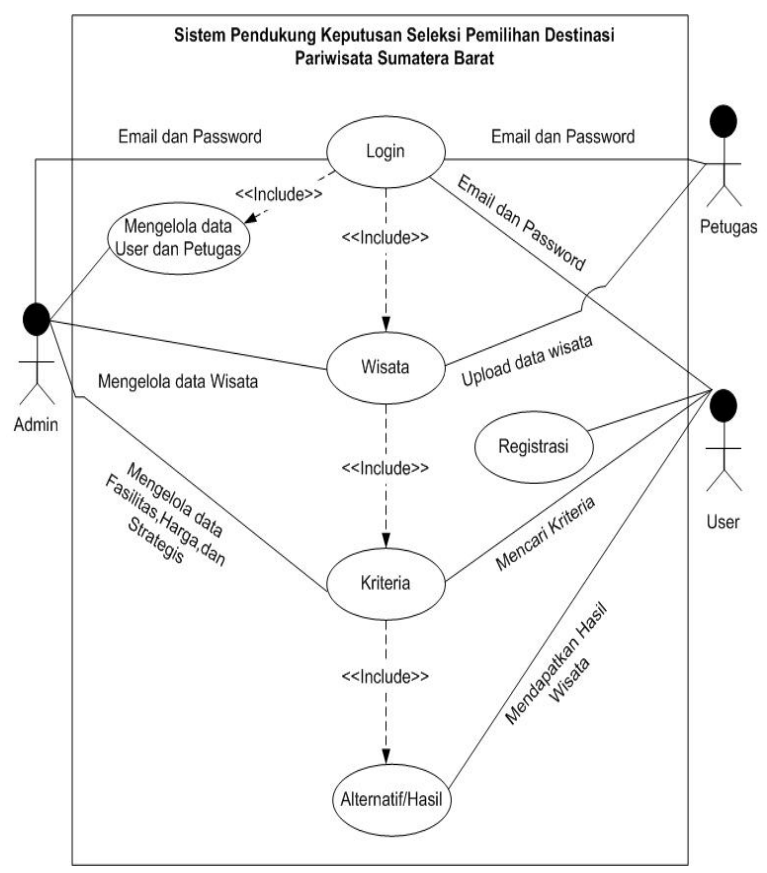

Gambar 1. Use-Case Diagram Admin,User dan Petugas

1) User

User adalah wisatawan yang menggunakan fasilitas web yang nantinya digunakan oleh pengguna user untuk mencari destinasi pariwisata yang sesuai dengan kriteria wisatawan.

\section{2) Admin}

Admin adalah pengguna yang nantinya bertanggung jawab untuk mengelola web tersebut.
3) Petugas

Petugas adalah pengguna yang akan memberikan informasi dari setiap daerah Kabupaten/Kota yang ada di Provinsi Sumatera Barat.

\section{Context Diagram}

Context Diagram yang dirancang akan membangun sistem pendukung keputusan pemilihan pariwisata Provinsi Sumatera Barat ini terdapat 3 external entity yaitu User, Petugas dan Admin. Context Diagram dapat dilihat pada gambar di bawah :

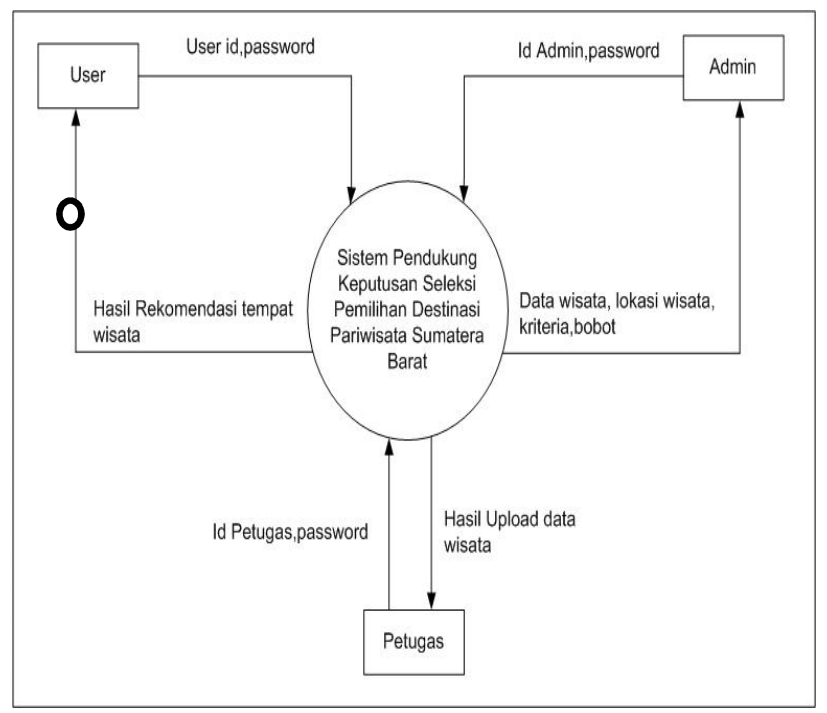

Gambar 2. Context Diagram Pemilihan Destinasi Pariwisata Provinsi Sumatera Barat 


\section{Activity Diagram User memilh Destinasi} Wisata

Proses dimulai dari wisatawan membuka aplikasi dan melakukan Login. Selanjutnya wisatawan memilih menu perjalananku, dan mencari kota mana yang ingin dituju. Setelah melakukan pencarian kota, secara otomatis wisatawan akan dialihkan ke halaman wisata sesuai daerah yang dipilih. Selanjutnya wisatawan disperintahkan untuk memilih tiga wisata yang ingin dikunjungi, setelah memilih secara otomatis akan diproses dan wisatawan akan mendapatkan hasil rekomendasi wisata yang diinginkan. Berikut dibawah ini proses user memilih wisata:

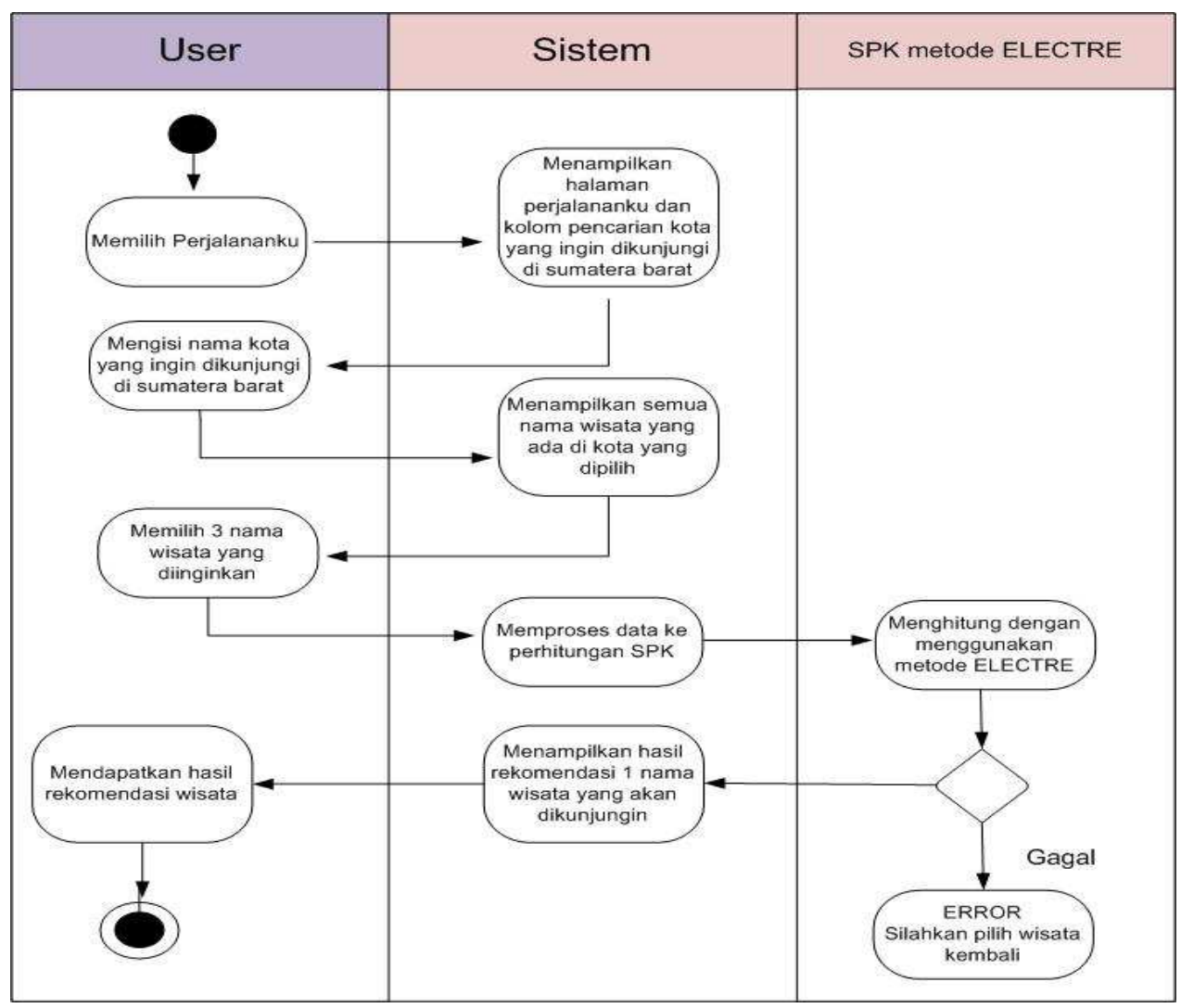

Gambar 3. Activity Diagram User Memilih Destinasi Wisata

\section{Entity Relationship Diagram (ERD)}

Entity Relationship Diagram (ERD) merupakan diagram yang memberikan informasi yang akan dibangun, disimpan dan digunakan, dimana entity saling berkaitan.
Berikut dibawah ini gambar ERD sistem pemilihan destinasi pariwisata yang ada di Provinsi Sumatera Barat: 


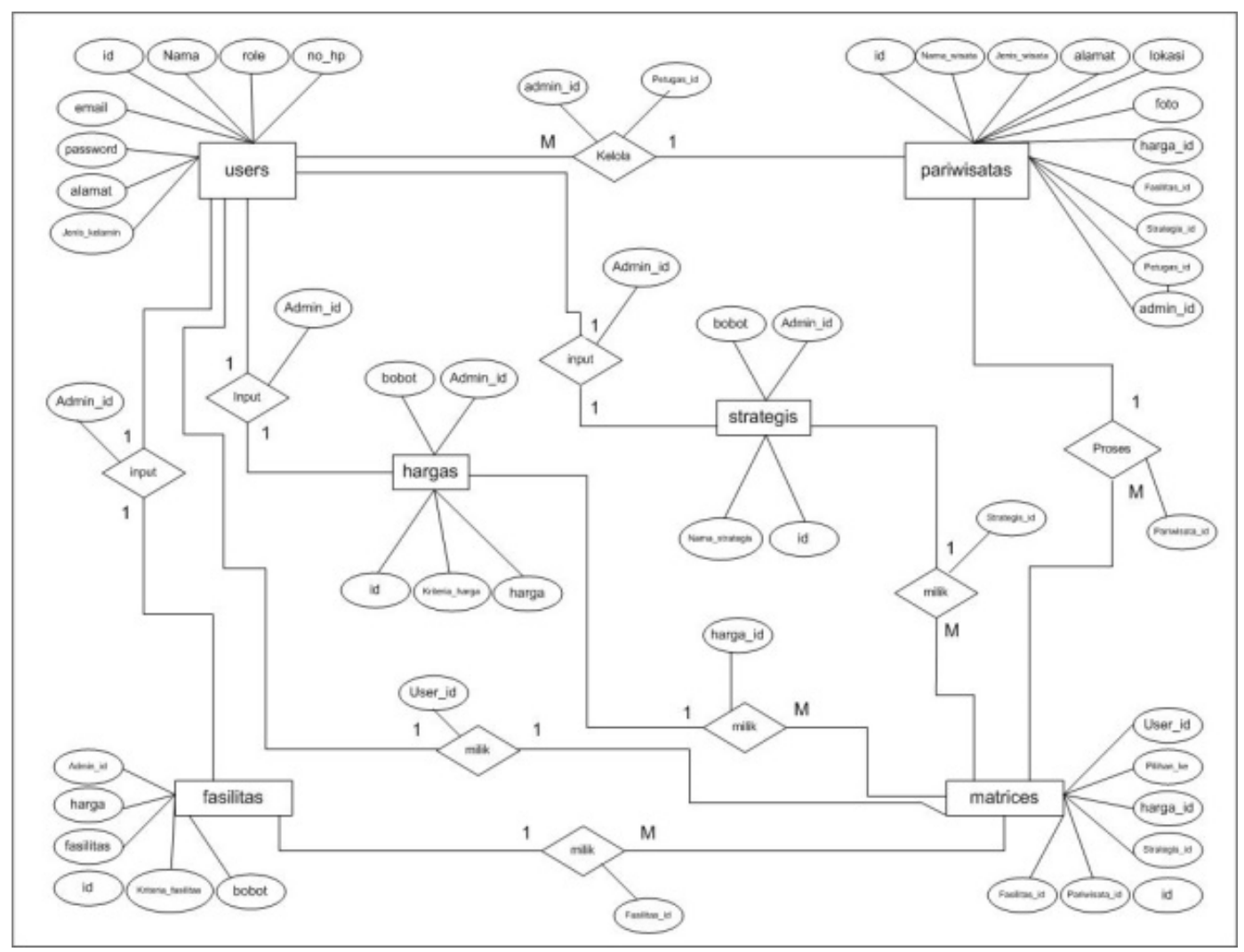

Gambar 4. Entity Relationship Diagram (ERD) Sistem Pendukung Keputusan Pemilihan Pariwisata Sumatera Barat

6. Desain Tampilan Halaman Awal Website

Desain aplikasi sistem ini merupakan rancangan aplikasi website yang akan dibangun seperti apa dari tampilan awal website hingga tampilan akhir website. Berikut ini merupakan desain tampilan awal website Sistem Pendukung Keputusan Pemilihan Pariwisata di Sumatera Barat.

\begin{tabular}{|l|l|}
\hline $\begin{array}{l}\text { Sistem Pendukung Keputusan Pemilihan Destinasi Pariwisata } \\
\text { Provinsi Sumatera Barat }\end{array}$ & Register Login \\
\hline SLIDE FOTO \\
\\
\hline Footer \\
\hline
\end{tabular}

Gambar 5. Desain Tampilan Halaman Awal Website

\section{HASIL DAN PEMBAHASAN}

\section{Implementasi Sistem}

Implementasi sistem adalah tahap menampilkan hasil dari desain yang dibuat kedalam pemrograman. Implementasi sistem ini dilakukan untuk mengetahui apakah sistem yang telah dirancang dapat berjalan dengan benar dan sesuai dengan desain yang dibuat sebelumnya.

\section{Halaman Index}

Halaman index merupakan halaman awal saat sistem pertama kali dijalankan. Halaman index pada sistem ini yaitu halaman awal yang menampilkan pariwisata Provinsi Sumatera Barat. Berikut tampilan halaman index: 


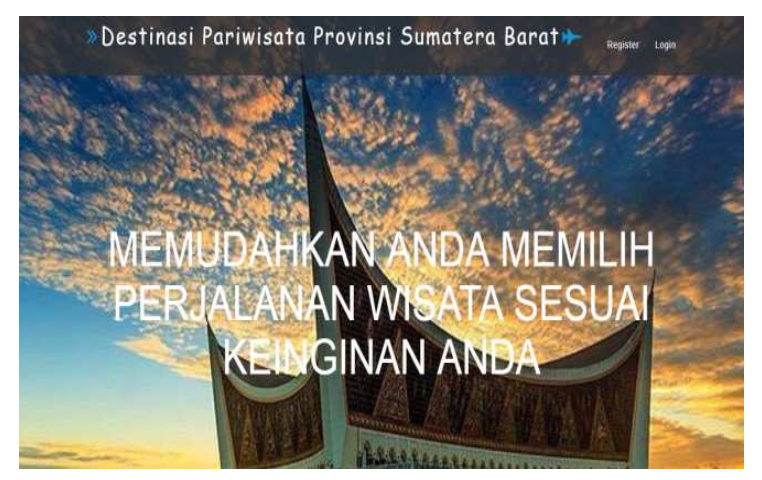

Gambar 6. Tampilan Halaman index

\section{Halaman Login}

Halaman Login adalah halaman yang digunakan user untuk masuk ke sistem. Halaman ini berisikan kolom E-mail dan password yang harus di isi agar dapat masuk ke sistem. Adapun tampilan rancangan halaman Login sebagai berikut:

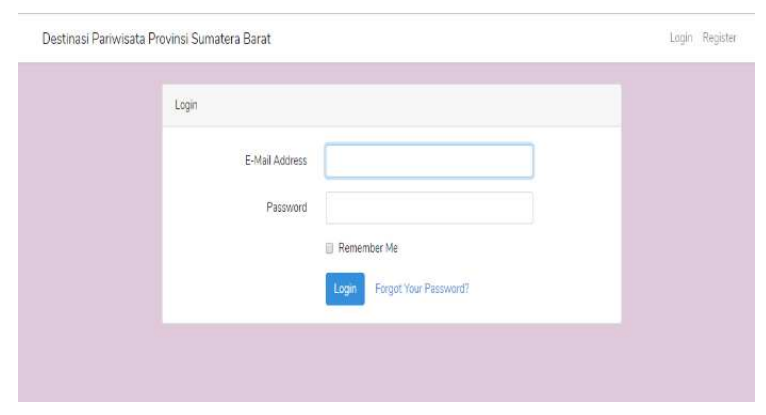

Gambar 7. Tampilan Halaman Login

\section{Halaman Admin}

Halaman Admin adalah halaman yang pertama muncul setelah admin melakukan Login dengan user id yang dimiliki admin. Berikut tampilan halaman admin :

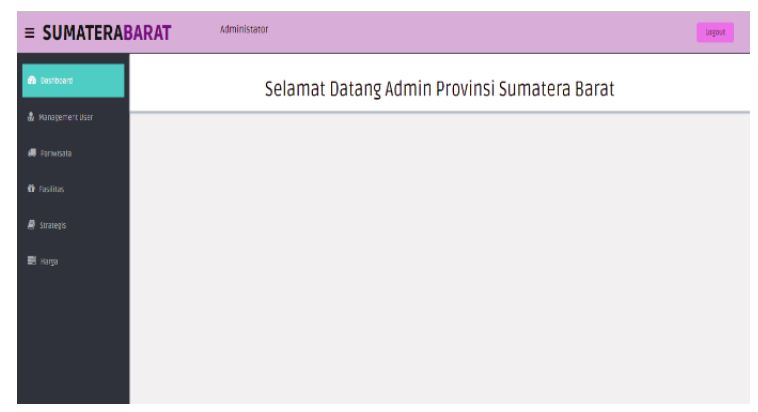

Gambar 8. Tampilan Halaman Admin

\section{Halaman Petugas}

Setelah petugas melakukan Login dengan memasukkan E-mail dan Password, maka petugas akan beralih ke halaman awal petugas sebagai berikut:

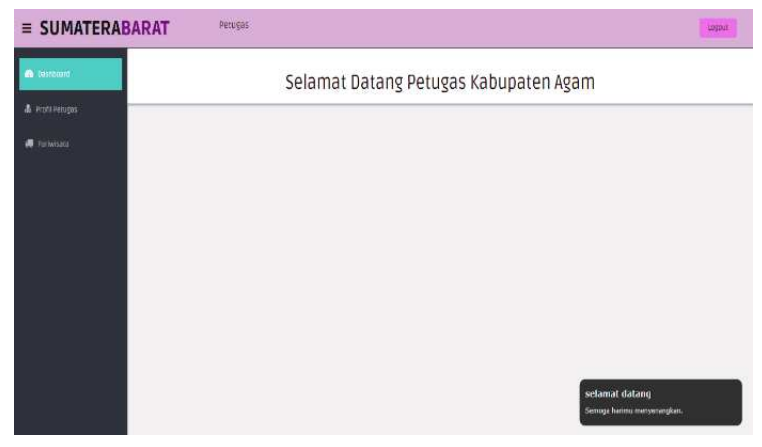

\section{Gambar 9. Tampilan Halaman Petugas}

\section{Halaman Awal Wisatawan}

Halaman awal wisata adalah halaman pertama yang muncul setelah wisatawan melakukan Login dengan memasukkan E-mail dan Password yang telah terdaftar sebelumnya, berikut merupakan tampilan dari halaman wisatawan :

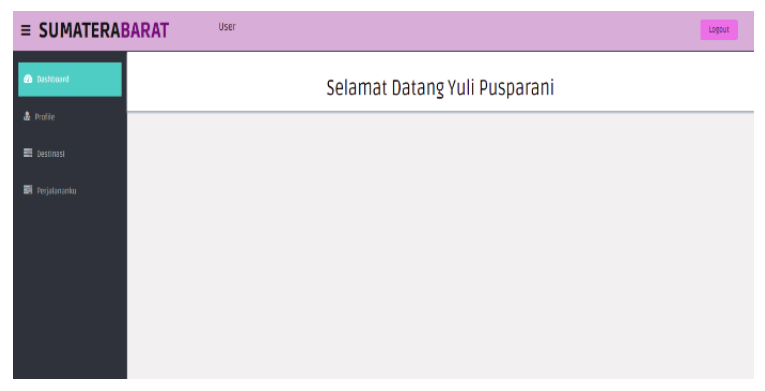

Gambar 10. Tampilan Halaman Awal Wisatawan

\section{Halaman Destinasi}

Halaman destinasi merupakan halaman yang digunakan wisatawan untuk mencari wisata yang diinginkan, dan halaman destinasi juga merupakan halaman awal memulai proses sistem pendukung keputusan pemilihan wisata dengan memilih 3 wisata yang mempunyai nilai bobot untuk dihitung dengan menggunakan metode ELECTRE. Berikut merupakan tampilan mencari wisata: 


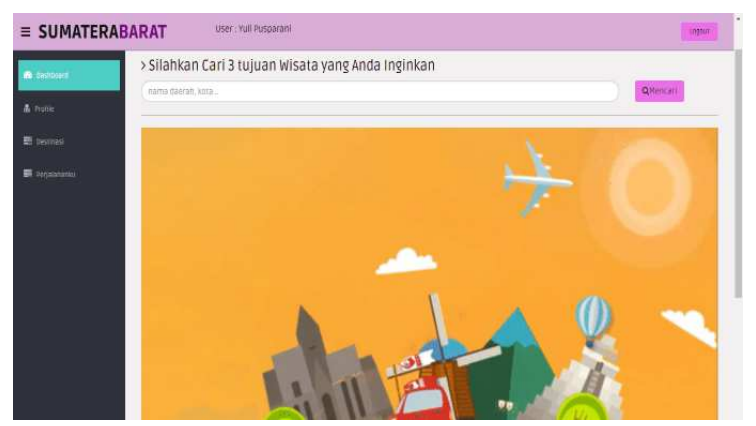

Gambar 11. Tampilan Halaman Mencari Wisata

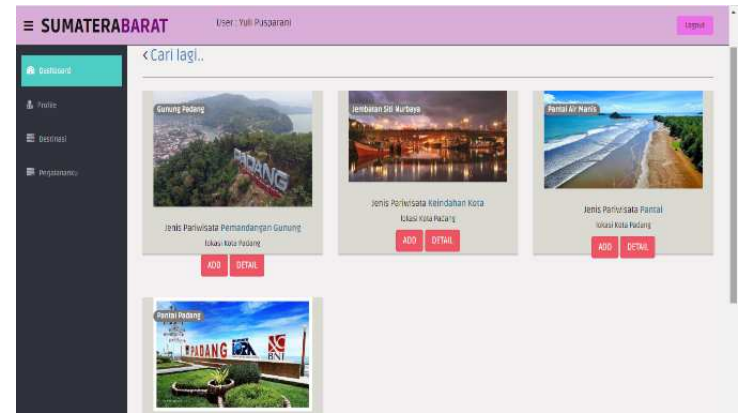

Gambar 12. Tampilan Halaman Wisata Sesuai Lokasi yang dipilih di Kolom Pencarian

\section{Halaman Perjalananku}

Halaman Perjalananku merupakan halaman proses sistem pendukung keputusan pemilihan destinasi pariwisata di Provinsi Sumatera Barat. Di halaman perjalanaku ini akan dihitung hasil dari 3 pilihan alternatif yang akan dijadikan tujuan tempat wisata dengan menggunakan perhitungan metode ELECTRE. Berikutlah hasil alternatif yang didapat dari 3 pilihan wisata yang diinginkan:

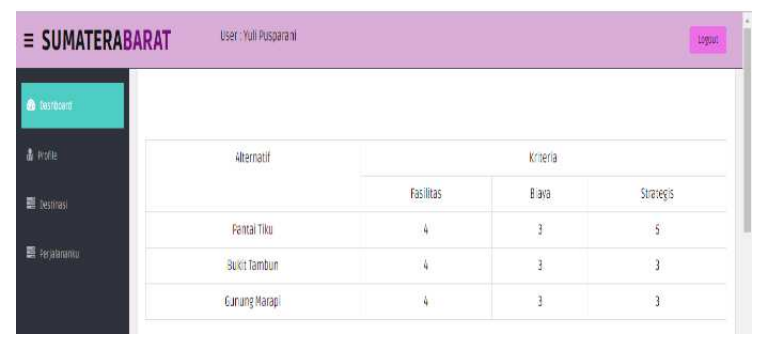

Gambar 13. Tampilan Halaman Perjalananku Hasil Proses Sistem Pendukung Keputusan Metode ELECTRE
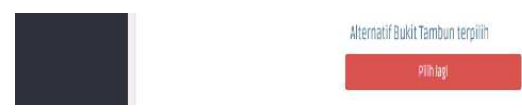

Gambar 14. Hasil Alternatif yang terpilih

\section{KESIMPULAN}

Adapun kesimpulan yang dapat diambil dari Rancang Bangun Sistem Pendukung Keputusan Pemilihan Destinasi Pariwisata Provinsi Sumatera Barat dengan Menggunakan Metode ELECTRE Berbasis Web adalah sebagai berikut:

1. Dengan adanya sistem ini dapat membantu pengunungan wisata atau wisatawan dalam melakukan pencarian tempat wisata sesuai keinginan wisatawan di provinsi Sumatera Barat.

2. Dengan pemanfaatan bahasa pemrograman Personal Home Page (PHP) dan Framework Laravel kita bisa mengembangkan sebuah sistem pendukung keputusan seperti sistem pendukung keputusan pemilihan destinasi pariwisata provinsi sumatera barat.

3. Dengan menggunakan metode ELECTRE dapat memudahkan dalam proses perangkingan yang berdasarkan penjumlahan terbobot dari rating kinerja pada setiap alternative pada semua atribut.

\section{DAFTAR PUSTAKA}

[1] Linda Marlinda. 2016. Sistem Pendukung Keputusan Pemilihan Tempat Wisata Yogyakarta Menggunakan Metode Elimination Et Choix Traduisant La RealitA (ELECTRE). Seminar Nasional Sains dan Teknologi 2016. 8 November 2016.

[2] Akhmad Busthomy, Sultoni.,dan Rudi Hariyanto, "Sistem Pendukung Keputusan untuk Pemilihan Objek Wisata di Kabupaten Pasuruan dengan Menggunakan Metode Fuzzy”. Jurnal Informatika Merdeka Pasuruan, vol. 2 no 1, pp. 33-55, 2016.

[3] Kusrini. Konsep dan Aplikasi Sistem Pendukung Keputusan, Andi offset, Yogyakarta. 2007.

[4] Irfan Surbakti. Sistem Pendukung Keputusan (Decision Support System). Surabaya: Jurusan Teknik Informatika Fakultas Teknologi Informasi Institut Teknologi Sepuluh November. 2002.

[5] Sandy Kosasi. Sistem Penunjang Keputusan (Decision Support System). Pontianak. 2002. 
[6] Sri Kusumadewi, Sri Hartati, Agus Harjoko, dan Retantyo Wardoyo. Fuzzy Multi Attribute Decision Making. Yogyakarta: Graha Ilmu. 2006.

[7] Syeril Akshaerari. Sistem Pendukung Keputusan Pemilihan Produksi Sepatu dan Sandal dengan Metode Elimination et Choix Traduisant la Realite (ELECTRE). Bandung. 2013.

[8] Dony Novaliendry, "Aplikasi Penggunaan Metode Promethee dalam Sistem Pendukung Keputusan untuk Penentuan Media Promosi, Studi Kasus: STMIK Indonesia". Jurnal Ilmiah KURSOR, vol. 5, no 2, pp. 104-111. 2014.

[9] Dony Novaliendry, Yeka Hendriyani Cheng-Hong Yang dan Hafilah Hamimi. "The Optimized K-Means Clustering Algorithms To Analyzed the Budget Revenue Expenditure in Padang". Proceeding of International Conference on Electrical Engineering, Computer Science and Informatics (EECSI 2015), 19-20 August 2015. 2015.

[10] Muhammad Salahudin, Indah Fitri Astuti, dan Awang Harsa Kridalaksana. "Sistem Pendukung Keputusan Berbasis Website untuk Pemilihan Destinasi Pariwisata Kalimantan Timur dengan Metode Elimination And Choice Expressing Reality (ELECTRE)". Prosiding Seminar Ilmu Komputer dan Teknologi Informasi. 1(1): 64-70. 2016. 